\title{
Espaços prisionais: Da corrupção dos costumes aos desafios da promoção dos direitos humanos na atualidade
}

\author{
BARROS, Ana Maria de ${ }^{1}$ \\ NASCIMENTO, Alan Marcionilo do ${ }^{2}$
}

\section{Resumo}

As relações políticas e sociais no Brasil são fortemente marcadas por uma ordem coronelista e clientelista. As relações entre o público e o privado, bem como a obediência às regras institucionais, é constantemente desvirtua do seu sentido original. As prisões brasileiras enquanto espaços marcados por essa mesma lógica da sociedade, termina por ter características singulares no que diz respeitos as relações entre os aprisionados, gerando códigos de conduta específicos. Além desses fatores tradicionais da sociedade brasileira, nas últimas décadas com uma maior intensificação de políticas neoliberais, as prisões passam a ser também um espaço onde o capital busca expandir seus lucros, com isso alguns dos problemas estruturais do nosso sistema prisional terminam por aumentar. Diante desse contexto buscaremos refletir sobre as possibilidades de promoção dos Direitos Humanos, levando em consideração as condições de organização das prisões brasileiras, enquanto estabelecimentos marcados por características estruturais da nossa sociedade; coronelismo e clientelismo, bem como os desafios impostos por uma política neoliberal.

Coronelismo. Clientelismo. Sistema prisional. Direitos Humanos. Neoliberalismo.

\section{Resumen}

Las relaciones políticas y sociales en Brasil son fuertemente marcadas por un ordén coronelista y clientelista. Las relaciones entre el público y el privado, así como la obediencia por las reglas institucionales, son constantemente desvirtuadas de su sentido original. Las prisiones brasileñas como espacios marcados por la misma lógica de la sociedad, tienen características singulares en lo que dice respeto a las relaciones entre los encarcelados, generando códigos de conducta específicos. Más allá de los factores tradicionales de la sociedad brasileña, en las últimas décadas con una mayor intensificación de las políticas neoliberales, las prisiones también pasan a ser un espacio donde el capital busca expandir sus beneficios, con eso algunos de los problemas estructurales de nuestro sistema prisional se intensifican. Delante ese contexto, buscaremos reflejar sobre las posibilidades de promoción de los Derechos Humanos, teniendo en consideración las condiciones de organización de las prisiones brasileñas, cuando establecimientos marcados por características estructurales de nuestra sociedad; coronelismo y clientelismo, bien como los desafíos impuestos por una política neoliberal.

Coronelismo. Clientelismo. Sistema prisional. Derechos Humanos. Neoliberalismo.

\footnotetext{
${ }^{1}$ Profa. Associada da UFPE, Doutora em Ciência Política (UFPE), Mestra em Educação (UFPB), Especialista em Sociologia (FAFICA), Graduada em História (FAFICA), Graduada em Direito (ASCES/UNITA), Coordenadora da Licenciatura Intercultural Indígena (CAA-UFPE), Vice- Líder do Grupo de Pesquisa: Educação, Inclusão Social e Direitos Humanos: UFPE/CNPq.

2 Mestrando em Direitos Humanos pela Universidade Federal de Pernambuco. (PPGDH-UFPE), Graduado em História e especialista em História do Brasil, pela Faculdade de Filosofia, Ciências e Letras de Caruaru. (FAFICA).
} 


\section{Introdução}

Para situar o debate que nos propomos a fazer neste artigo, iniciamos este texto por uma caracterização do contexto histórico brasileiro para que possamos situar melhor nosso objeto de estudo. Começaremos, por uma rápida passagem na organização do poder político no Brasil, onde as relações políticas são marcadas, culturalmente, por elementos ligados ao coronelismo, clientelismo político e à herança populista. Elementos esses, profundamente arraigados ao nosso cotidiano, com mais continuidade do que se imagina. São expressões da vida política que formam hábitos e costumes que privilegiam as relações sociais na perspectiva do favor, das amizades, do "jeitinho brasileiro" na corrupção dos costumes, do tráfico de influência.

Para que possamos compreender como em nossa vida social, esses elementos de pessoalidade, afetividade, parentesco e amizade desviam o caráter público que deveriam ter as relações coletivas que irão se reproduzir em todas as esferas da sociedade e claro, na prisão traçamos uma reflexão sobre a organização do poder político no Brasil e suas consequências na formação: Moral, ética e pública da vida cotidiana brasileira e como se refletem na prisão como espaço micro onde estão também reproduzidas os elementos de nosso cultura política.

\section{Coronelismo, clientelismo e populismo na vida nacional}

Coronelismo designa, certas práticas políticas e sociais próprias do meio rural e das pequenas cidades do interior brasileiro. Sua relação histórica remonta ao período regencial brasileiro, especificamente $1831 \mathrm{com}$ a instituição da Guarda Nacional, corporação paramilitar, que arregimentava homens livres, funcionava como o braço armado do poder civil. Catalisava a insatisfação dos civis (proprietários rurais) com a ineficiência do Estado. Acabou reproduzindo, em grande parte, as diferenças sociais, de renda, de propriedade e prestígio. O título de coronel cabia sempre às pessoas mais influentes. A Guarda Nacional tratava desde a manutenção da ordem local ao combate às rebeliões. Mesmo posteriormente, quando seu poder cedeu ante a organização do exército e das milícias profissionais estaduais, mesmo após sua extinção em 1922, o título de coronel continuou sendo usado para indicar "chefe político". Passemos por algumas definições essenciais: Leal (1975) define o coronelismo como uma forma de adaptação entre o poder privado e um regime de extensa base representativa. Enquanto Queiroz (1976) percebe o coronelismo como caracterizado por uma relação de compromisso entre ambos, tendo como consequência o falseamento do voto e a desorganização dos serviços públicos locais. Esse é um fenômeno produzido no cotidiano da vida política, dele emergem vínculos que favorecem a promiscuidade política e a elasticidade de valores em nossa sociedade.

É uma fonte específica de poder, que floresceu durante a $1^{\text {a }}$ República e cujas raízes remontavam ao império; já então os municípios eram feudos políticos, que se transmitiam por herança, não configurada legalmente, mas que existiam de maneira informal. (LEAL, 1975, p. 76). 
O Coronelismo é uma das formas adotadas pelo mandonismo local no Brasil, assumindo algumas variações regionais: em grande parte do Brasil e no Nordeste. É uma afirmação do poder privado, onde uma elite controladora do poder político, social e econômico, encarnada no próprio proprietário rural, ocasionalmente no burocrata, comerciante ou profissional liberal do interior do Brasil comandam os interesses hegemônicos, no domínio familiar ou público.

O coronel tinha a prerrogativa de indicar ou afastar ocupantes de cargos federais e estaduais ${ }^{3}$. O voto estava ligado à condição de ser "alfabetizado", na realidade, saber assinar o nome. $E$, dessa forma, na cidade e na zona rural, ensinar os camponeses e a população a assinar o nome, constituiu-se num elemento polarizador da vida social e política dos municípios, centros de decisões, contribui para a formação do estereótipo popular do coronel. "homem que protege os amigos e persegue os desafetos", "cabra macho", "cabra brabo", "macho com as mulheres", etc., dominam seu eleitorado através dos cabos eleitorais.

Se fizermos uma análise refinada dos resquícios do coronelismo em nossa sociedade, perceberemos que alguns aspectos de nossa vida cotidiana contribuíram decisivamente, para 0 desenvolvimento desse tipo de mandonismo: a dificuldade financeira da metrópole em administrar todo território brasileiro, incentivando uma colonização de caráter privado e individualista com isolados núcleos de povoamento, a cana - de açúcar e a pecuária exigiam grandes extensões de terras para o seu desenvolvimento, áreas afastadas dos centros de decisões. A experiência coronelista, direta ou transmitida do eleitorado urbano brasileiro, permitiu, no entanto, o surgimento de formas de fidelidade e adesão políticas, ainda permeadas da lógica voto mercadoria. Há chefes políticos tipicamente urbanos que pautam suas carreiras, visando atender benefícios eleitorais como empregos, obras públicas, acesso facilitado às instituições públicas ${ }^{4}$, tendo em troca a garantia de votos, dando continuidade a uma política de clientela ${ }^{5}$. Há uma diferença fundamental entre o clientelismo do coronel rural para o chefe político urbano. O segundo não é, necessariamente, monopolizador de recursos e meios de existência da população e do eleitorado (principalmente nas médias e grandes cidades). Podem até encaminhar os votos com considerações ideológicas, assumindo papéis "progressistas" fundindo elementos como nacionalismo, populismo e clientelismo político, o que os aproxima é o sistema de favor e de tutela.

A falência econômica do coronel, associada à carência do poder político assentado em novas bases, criam o espaço adequado ao processo de barganha que começa a se desenvolver. No âmbito do localizo, o coronel enfeixa a ambiguidade de uma reação polarizada: de um lado o mandonismo e do outro o clientelismo. De um lado, age o

\footnotetext{
3 Juízes, Fiscais, Policiais, Coletores de Impostos, Professores, etc...

${ }^{4}$ Tráfico de influência.

${ }^{5}$ A prática do toma lá dá cá, compra de votos dos eleitores ou mesmo dos vereadores, deputados, senadores, prefeitos, governadores, presidentes da república, situações bem explicitadas nos escândalos de corrupção recentes e antigos denunciados e outros que temos acompanhado os seus julgamentos, através da imprensa ou do poder judiciário.
}

$$
\text { através da imprensa ou do poder judiciário. }
$$


senhor durão que ameaça e pune os adversários. Do outro lado, o magnífico protetor que dá arrimo aos seus jurisdicionados a acoberta os crimes mais hediondos, desde que garantam a incolumidade do seu poder e do seu prestígio. (GARCIA, 1991, p. 27).

Outro elemento necessário à nossa análise é o populismo que nasce para romper e combater o coronelismo, mas que incorpora muitos elementos clientelistas. O populismo nasceu na América Latina, mais especificamente, a partir da crise de 1929, sendo mais comum na Europa e nos Estados Unidos da América. É marcado por mudanças políticas que levam, segundo o caso, à ruptura com formas tradicionais de dominação autoritária, alguns casos podem ilustrar a nossa afirmação: o getulismo no Brasil e o peronismo na Argentina. Germani (1960) inclina-se a ver o populismo como consequência das defasagens ou falta de sincronia do processo de modernização das sociedades latino - americanas, principalmente quanto à promoção de altos índices de mobilização social ${ }^{6}$. Em relação aos processos de integração das novas estruturas sociais geradas pelos processos de urbanização e industrialização. Tella (1989) define o populismo como resultante de uma aliança entre setores populares e urbanos mobilizados pela "revolução das aspirações" e alguns segmentos de camadas mais favorecidas portadoras de motivações contra o "status quo" e capazes de formular uma ideologia fortemente emocional. Jaguaribe (1973) por outro lado, destaca, em sua análise, uma relação do tipo carismático, entre a liderança individual e as massas urbanas, de que resultam fortes limitações ao conteúdo e à estabilidade das mudanças sociais aparentemente usadas por esses movimentos em suas etapas iniciais.

Destacamos, na abordagem de Weffort (1968) o populismo como resultado e como poderoso agente de transformações registradas no sistema econômico, na estrutura de classes e nos padrões de domínio político na América Latina. Transformações essas que tiveram seus episódios desencadeantes, primeiro no impacto da crise mundial de 1929 e, posteriormente, nos rápidos processos de industrialização originados pelos efeitos internos dessa crise em quase todos os países latino-americanos.

O caráter eminentemente urbano dos sustentáculos políticos do populismo imprime uma importante diferença entre os movimentos aos quais foram estes termos em outras partes. O período populista é extremamente ambíguo e instável, pois, de um lado, contribuiu para a liquidação de formas tradicionais de domínio e prenunciam outras, que continuam expressando a subsistência de problemas, desigualdades, pobreza, dependência e rigidez sociais, que o populismo, pelo menos em seus momentos iniciais, pareceu disposto a solucionar.

A forma como se origina e evolui o poder político no Brasil tem implicações diretas para a evolução da organização social, já que, de forma espontânea ou deliberada, esta se organiza e se desenvolve para atender aos interesses das camadas representadas na estrutura de poder.

\footnotetext{
${ }^{6}$ Com a consequente produção de massas "disponíveis" em um contexto urbano, ainda vinculado a valores tradicionais e suscetíveis de corresponder a ideologias autoritárias elaboradas por elites.
} 
O regime político cujas bases de sustentação estejam fortemente implantadas no poder local, dificilmente consegue organizar um sistema de ensino capaz de executar suas diretrizes centrais. Neste caso, inexiste uma política educacional definida em termos de estrutura unificadora para toda a nação. Geralmente o reforço do poder local se faz segundo uma política de clientela que mina pela base qualquer tentativa de organização do ensino, segundo normas, regras e princípios nacionais. (ROMANELLI, 1978, p. 53).

A sobrevivência desse sistema de poder está ligada à dependência da ordem social vigente, comum nas sociedades oligárquicas, onde as bases são definidas na hipertrofia do poder local, onde elementos do coronelismo, clientelismo e populismo se fundem construindo uma cultura política específica. O florescimento da cultura nacional a partir dos anos 20 , com a semana de arte moderna, posteriormente o movimento tenentista, o movimento dos pioneiros da educação, a Revolução de 30 , indicam a criação de novas modalidades de consciência nacional.

Esses acontecimentos não são apenas políticos, nem estritamente internos. Eles são em geral, manifestação das relações, tensões e conflitos que os setores novos ou nascentes no país estabelecem com a sociedade brasileira tradicional e com as nações mais poderosas com as quais 0 Brasil está em intercâmbio. (FREITAG, 1989, p. 65).

Apesar do desenvolvimento econômico do Sudeste brasileiro neste período é importante lembrar que o próprio colapso do modelo de substituição das importações se deu pela inelasticidade do mercado interno. Dada a predominância da população rural, marginalizada da sociedade de consumo, em relação à população urbana. A inserção de um maior contingente populacional no novo sistema econômico ocorreu pela manutenção de uma estrutura arcaica e pelos baixos níveis dos salários da grande maioria da população. A característica política essencial para a análise deste período é a evolução e destruição do populismo. Marcado em Getúlio Vargas, por tendências nacionalistas, a criação de um mito e de um modelo.

Se ruptura houve, nesse período, do ponto de vista de político, esta se deu com o aparecimento da política de massas, que ligou diretamente as camadas populares aos líderes políticos de forma carismática. Essa política de massas é compreensível na medida em que se leva em conta a composição rural-urbana do proletariado industrial. Seus horizontes e valores culturais são profundamente marcados pelos valores e padrões do mundo rural. Neste predominam formas patrimoniais $e$ comunitárias de organização do poder, de liderança, submissão, etc. (ROMANELLI, 1978, p. 56). 
Alguns elementos estavam no universo do trabalhador agrícola, como o misticismo, a violência e o conformismo como soluções tradicionais, perfil este que se altera na vida na cidade, modifica-se na indústria só que de forma parcial e contraditória, essa massa que se amplia nos centros urbanos é a fonte de alimentação do populismo. Ligando-se através da relação entre o líder e a massa, através da ideologia do nacionalismo econômico, é como se consolida o populismo de Vargas. Juscelino Kubitschek tentou conciliar o populismo de massas no plano político, abraçando o desenvolvimento industrial baseado na política de associação com empresas estrangeiras, o que acabou enfraquecendo o modelo populista. O impasse a ser enfrentado era o de compatibilizar os modelos econômicos e políticos: optando pela manutenção da orientação econômica e mudança na orientação política. Ou optando pela manutenção da orientação política e mudança na orientação econômica.

Opção feita, de forma menos consciente, por Jânio quadros e, talvez, mais consciente por Jango (João Goulart), o último tentando compatibilizar, mantendo o modelo político (nacional-desenvolvimentista) e modificando a orientação econômica que havia assumido o populismo no Brasil, realizando alguns ajustes, que passaram, necessariamente, pela redefinição do papel do Estado como incentivador da economia, intervindo, drasticamente, na esfera rural-agrícola, reaproximando os interesses da burguesia nacional com os do proletariado.

O golpe de 1964 foi desencadeado pelos grupos que acreditavam na conveniência da opção inversa, ou seja, na compatibilização, mantendo-se a orientação econômica (com base no capital externo) e mudando-se a política, abandonando-se o nacional-desenvolvimento em benefício de um modelo associado. (ROMANELLI, 1978, p. 67).

É importante destacar deste período as importantes mobilizações populares, o crescimento da participação popular de forma mais consciente e engajada na vida do país. Através das Ligas Camponesas, do Movimento Sindical, dos partidos de esquerda, do Movimento Estudantil, setores avançados da Igreja Católica, etc. Só que, também, ao mesmo tempo, se desenvolve no país e no mundo a campanha anticomunista, patrocinada pelos E.U.A, buscando brecar o avanço do socialismo no mundo, e, especificamente, na América Latina, tentando evitar que, a exemplo de Cuba, outros países adotassem o socialismo. Encontrando no Brasil terreno fértil para a sua pregação, através dos setores reacionários da Igreja Católica, dos latifundiários que temiam a Reforma Agrária. Enfim, todos os opositores do modelo populista nacionalista adotado no governo Jango. Após a queda de Jango pela ditadura militar de 1964, ocorre um aprofundamento do domínio das antigas oligarquias aliadas aos interesses do regime militar. A implementação das novas políticas tem como base assegurar através da educação e da manipulação dos meios de comunicação e outros setores da sociedade o "consenso" para aceitação do novo regime, associado às práticas de perseguição política, torturas, prisões ilegais, patrulhamento ideológico, bipartidarismo, etc. $O$ acesso ao serviço público passou a ser privilégio dos protegidos dos defensores da ditadura militar, é reforçado ainda mais no Nordeste o modelo clientelista já conhecido. 
Mesmo após o fim da ditadura militar, ainda assistimos hoje, às práticas clientelistas determinarem o acesso ao serviço público. E o emprego público, mesmo contrariando a constituição de 1988 continua, em particular, nas cidades do interior do Nordeste a se constituir em uma mercadoria de troca de voto, onde os vícios do privilégio, do tráfico de influência reacendem. $O$ clientelismo apresenta-se como um mecanismo restritivo da democracia brasileira. A outra restrição é imposta pelo populismo, aliado aos resquícios da ditadura e da repressão. Quando tomamos as referências na História da política brasileira, identificamos o clientelismo/coronelismo como mecanismos que dissimulam a participação formal, como fenômenos de origens rurais, que atuam na esfera do privado, e o populismo, como fenômeno urbano e que opera na esfera do público. "O pêndulo do Estado para uma postura mais democrática ou mais ditatorial resulta do nível de ameaça que o modelo capitalista enfrenta" (GARCIA, 1991, p. 47).

\section{Qual a relação entre coronelismo, clientelismo, populismo e prisão?}

Se a prisão é um palco de repercussão da sociedade brasileira, todos os hábitos referentes à nossa vida social lá estão refletidos em menor ou maior grau. Assim como nós, cidadãos livres, negociamos vantagens, também os detentos criam as suas regras a partir da cultura da cadeia e suas lideranças são herdeiras das práticas de favor e tutela descritas anteriormente: Assim, 0 melhor espaço para dormir, regalias e benesses se compram, como as compramos fora da prisão. Ter amigos, fazer parte de um grupo dominante é sinal de visibilidade e de pertencimento, se torna parte da vida cultural e social da cadeia, que possui seus próprios ritos, regras e espacialidades.

Faoro (2001) lembra que constituímos uma sociedade patrimonialista, fincada na hegemonia de grupos de poder, que se revezam na esfera dominante através de acordos e privilégios. Sendo assim, nos ambientes sociais as relações reproduzem os acordos pessoais e políticos e as pessoas que escolhemos para nossas parceiras, onde as práticas da vida da intimidade social, do mundo da vida privada, são levadas as experiências do mundo público.

Ainda reflete Faoro (2001) ao demonstrar que estes costumes aparecem nas escolhas que fazemos na vida política, por exemplo, onde pais, filhos, irmãos parentes criam hordas nepotistas no poder judiciário, executivo e legislativo, o espaço público vai se transformando no espaço dos interesses pessoais do líder no poder, reforçando o ditado popular: "para os amigos tudo, para os inimigos a lei".

As regras do mundo da cadeia estão definidas dentro do processo de prisionalização:

Prisionalização é o fenômeno que se dá com a entrada do indivíduo no sistema prisional, sua assimilação. Este fenômeno ocorre com maior intensidade quando se conjugam os seguintes fatores: pena longa; personalidade instável; ruptura completa com o mundo exterior mediante visitas; disposição e capacidade para integração à vida na prisão; aceitação 
incondicional dos dogmas e princípios da sociedade carcerária; contato com pessoas de orientação similar; interesses em participar nos jogos e nas práticas sexuais "anormais". (RUDINICK, 1999, p. 553).

Assim, no mundo da cadeia dominada pelo mundo do crime as lideranças escolhem seus amigos, parceiros, e seus inimigos, criam teias de proteção e de perseguição, às vistas de agentes do Estado que compactuam com o comando paralelo, que de forma articulada determina, atuando em redes de poder determinam as leis da cadeia, também denominada de cultura da cadeia com lideranças que podem contribuir para a pacificação da prisão, mas podem se transformar em comandos perigosos, como aqueles que deram origem às facções criminosas que dominam as prisões no Rio de Janeiro, São Paulo, Espírito Santos e muitos Estados brasileiros, cujas ações violentas e de confronto ao Estado de Direito, relembram os coronéis autoritários de obras da literatura brasileira, em particular em Jorge Amado, em Terras dos Sem fim, Gabriela Cravo e Canela e Tocaia Grande.

Observando estas regras disciplinares da cadeia, encontramos muito dos códigos de honra e poder que nos rodeiam, por caracterizar o império da lei do mais forte, do poder econômico com o advento da dominação do tráfico de drogas, de armas nas cadeias, da violência explícita e simbólica dos que não acreditam no Estado de direito, inclusive, muitos de nós que escrevemos sobre o tema. É nesse sentido que as lideranças e o poder de vida e de morte se estruturam nas relações de força e poder de onde vêm os sujeitos privados de liberdade, reproduzem no mundo do crime as relações de poder de onde são oriundos na sociedade brasileira. Vale salientar, que se some a esta relação de extrema opressão os elementos tradicionais de violações de direitos humanos já denunciados pelos organismos internacionais, a exemplo da Anistia Internacional e Human Rights Watch.

\section{A prisão e os direitos humanos no Brasil}

A prisão brasileira começa a ocupar espaços nos debates relativos aos direitos humanos no Brasil principalmente em função das atrocidades praticadas nas ditaduras do período republicano, mas principalmente na recente ditadura militar. Destacaria a análise de Luciano Oliveira que ao relacionar os direitos humanos e o pensamento de esquerda no Brasil demonstra como sempre fomos indiferentes aos problemas provocados pelas violações dos direitos humanos, e como passamos a perceber a sua importância quando os militantes da esquerda brasileira passaram a ser vitimados pelos excessos autoritários ocorridos no período da ditadura militar. No prefácio de seu livro, Claude Lefort reforça a importância das questões levantadas por Luciano Oliveira sobre a relação entre a esquerda brasileira e o espaço para o debate sobre os direitos humanos no Brasil.

Essa é uma observação que me parece essencial para compreender a amplitude da mudança de perspectiva dos atores da esquerda: o tema da "causa do povo" aliava-se nos militantes marxistas revolucionários, se não uma ignorância, pelo menos a uma indiferença em relação às necessidades e aspirações próprias a camadas específicas; "o povo empírico", 
não tinha importância aos seus olhos (...) A opinião pública só se apavorou com a violência da repressão quando ela já não golpeou somente os comunistas e terroristas, mas se abateu sobre padres, membros das profissões liberais e cidadãos comuns. (LEFORT, IN, OLIVEIRA: 1996, p. 2-3).

A rejeição da tortura e das violações de direitos humanos por parte de setores de classe média, que antes apoiaram os governos autoritários no Brasil foi importante, passaram a recuar de sua posição inicial quando se consolidou a prática da tortura de forma generalizada, principalmente atingindo-os diretamente.

[...] esse fenômeno aparece na ditadura de Vargas, mas de maneira marginal, como vimos, pois, a grande maioria dos perseguidos pelo regime são militantes de esquerda provenientes das classes populares: Operários, artesãos, pequenos comerciantes e funcionários. Já durante a ditadura militar essa proporção se inverte: mais da metade das pessoas presas a partir de 1969 eram estudantes e profissionais com título universitário. (OLIVEIRA, 1996, p. 44).

Este tipo de realidade expôs a sociedade brasileira, mas particularmente as suas elites políticas e intelectuais em um estado de medo e perigo permanente. E nesse sentido, o tema dos direitos humanos no Brasil passará a ser identificado com a luta pelos direitos dos prisioneiros políticos do regime militar (OLIVEIRA, 1996, p. 63).

Com efeito, a partir do momento em que o movimento renovou seus objetivos, voltando-se para a defesa dos direitos dos presos comuns (...) a ideia de direitos humanos começou a ser desvalorizada pela opinião pública, e os seus militantes começaram a conviver com a incômoda acusação de serem "defensores de bandidos. (PERALVA, 2000, p. 74).

Peralva (2000) ao analisar os problemas que são resquícios da continuidade autoritária na vida política brasileira aponta para o fato de que o quadro legal herdado do regime autoritário é um obstáculo quase intransponível a qualquer tentativa de reforma da polícia que no retorno à democracia não sofreram substanciais mudanças no que concerne às práticas fora de um regime de exceção, compreende a autora que isso deveu-se ao imbricamento entre o antigo regime autoritário e o regime nascente, no quadro de uma transição longa e difícil que permanece na atualidade e facilita a relação perigosa entre Estado e crime.

Oliveira (1996) e Peralva (2000) identificam que o vazio da ordem pública teria criado espaço para que de um lado, a criminalidade violenta se desenvolvesse e por outro, os prisioneiros e bandidos comuns não fossem aceitos como sujeitos de direitos humanos; eles se diferenciavam em qualidade dos prisioneiros políticos, que se encontravam aprisionados por se confrontarem ao regime militar. Havia um sentimento de igualdade e a classe 
média conseguia se colocar no lugar daqueles prisioneiros, muitos vistos como heróis da resistência à ditadura7. "O preso político não perde a auto - estima nem a estima dos outros. Ele sofre em todas as dimensões da sua vida, mas permanece um homem que pode olhar de frente. Não está diminuído" (CELIS E HULSMAN, 1982, p. 32).

As condições prisionais tornam as prisões espaços de explosão dos mais variados conflitos, pouco se tem estudado motins e rebeliões, sabe-se pouco das motivações e a informação que chega até a sociedade é a informação do Estado, pouca validade tem a opinião dos prisioneiros, a rigidez do espaço prisional faz com que a imprensa não tenha acesso a versão dos detentos, e o que se sabe destes movimentos é o que é apresentado pelos programas de televisão ou a visão oficial.

Os relatórios internacionais de instituições como: Anistia Internacional, Human Rights Watch, Justiça Global, Comissão Interamericana de direitos Humanos, entre outras, ocuparam importantes espaços na política internacional, denunciando as violações de direitos humanos no Brasil, associadas a algumas instituições nacionais. A mais importante organização envolvida na fiscalização das condições carcerárias é a Pastoral Carcerária da Conferência Nacional dos Bispos do Brasil (CNBB). Com Padres e outros voluntários por todo país, a Pastoral Carcerária oferece assistência religiosa aos detentos enquanto também fiscaliza as condições e o tratamento aos presos. Representantes da Pastoral Carcerária, por terem ganho a confiança dos detentos, normalmente atuam como negociadores durante as rebeliões. (ANISTIA INTERNACIONAL: RELATÓRIO, 2004, p. 2).

Salla (2000) ressalta a necessidade de estudos mais aprofundados sobre as rebeliões e fugas, fenômenos que estão ligados ao problema estrutural da prisão: deterioração dos espaços físicos e locais de encarceramento, superlotação, condições de higiene, ausência de assistência jurídica, de saúde e educação, corrupção, incompetência administrativa, além da constância da prática da tortura. A desconfiança e o medo que imperam nas prisões brasileiras, o desconhecimento do que se passa no seu interior, de como e por que explodem os conflitos, nos levam a conhecer apenas um lado da argumentação. Motins e rebeliões, porque acontecem? Como poderiam ser evitados? Essa é a mais complicada investigação, caso o pesquisador seja mais ousado: pois terá que lidar com as duas faces da violência na prisão: a hierarquia militar e a hierarquia do mundo do crime.

A seletividade, a reprodução da violência, a criação de condições para maiores condutas violentas, a corrupção institucionalizada, a concentração de poder, a verticalização social e destruição das horizontais ou comunitárias não são

7 - A Igreja Católica, principalmente a CNBB e a OAB neste período iniciaram um amplo movimento denunciatório, sensibilizando os mais variados setores sociais contra a tortura e as violações de direitos Humanos. 
características conjunturais, mas estruturais do exercício de poder de todos os sistemas penais. (SALLA, 2000, p. 15).

São inúmeras as situações de poder e degradação que podem ser observadas nas prisões no dia-a-dia repetitivo e alienante, onde não apenas a dignidade humana é ofendida pela tortura de policiais e carcereiros, mas também pelo código de conduta aplicada na prisão pelos prisioneiros (as). A elite da cadeia julga e decide a vida de outros presos (as). Penas simples e outras que podem chegar à pena capital. Delatores, devedores, estupradores são vítimas de espancamento e morte na prisão, a lei do silêncio impera. $O$ segmento LGBT é submetido a situação de inferioridade, o ambiente machista e violento, não respeita quem nega sua virilidade e força. São tratados com desrespeito, agressão e subordinação, submetidos a humilhações constantes, separados em muitas unidades prisionais para a garantia de sua sobrevivência. Sua presença na frente das famílias dos detentos pode ser considerada falta grave, uma afronta às leis da cadeia. Estas regras teriam nascido da necessidade de auto regulação, que através delas garantem uma convivência "pacífica" na cadeia de acordo com (VARELA, 2002, p. 46-56). Assim, a rotina da prisão banaliza as situações de violações, de inferiorização, mas podem estourar em graves conflitos que produzem em geral episódios com resultados desastrosos.

Para Zafaroni (1991) e Smith (s/d) o resquício da continuidade autoritária na América Latina faz da prática da tortura ainda em método comum do trabalho policial ou do poder de punir na prisão. Dessa forma, o discurso dos direitos humanos não encontra espaço, mas inimigos no interior das prisões.

Além destas violações, verifica-se na operacionalidade social dos sistemas penais latino-americanos um violentíssimo exercício do poder à margem de qualquer legalidade. Nesse sentido, basta rever qualquer informe sério de organismos regionais ou mundiais de direitos humanos para comprovar 0 incrível número de sequestros, homicídios, torturas e corrupção cometidos por agências executivas do sistema penal ou por seus funcionários. (ZAFARONI, 1991, p. 29).

Lemos-Nélson (2002, p. 29-30) descreve como ocorreu a institucionalização das práticas de tortura e de execuções no Brasil, e como são tratadas pelas autoridades. Denúncia que são omissas e corroboram para a manutenção do padrão de graves violações dos direitos humanos. Situações que se explicitam com maior visibilidade em arquivamentos dos inquéritos, na caracterização de tortura como crime de "lesão corporal", ou mesmo quando o assassinato da vítima se deu em situação de resistência à prisão.

Maia (2002, p. 78) analisa que a prática da tortura provoca a fragilização da vítima, destrói sua resistência moral, por dificuldade de resistir às dores físicas ou pressões psicológicas; o torturador exerce um poder que só se manifesta porque a vítima está sob seu inteiro domínio; denuncia o quanto o judiciário brasileiro tem absolvido os acusados por falta de provas dada a pouca credibilidade dos depoimentos das vítimas, por serem criminosos. 
A mudança de perfil do detento: mais jovem, mais escolarizado, mais revoltado, e com imensa dificuldade de internalização de normas, na prisão, é cada vez mais ameaçador ao cidadão comum, o que tem resultado em situações de confronto nas unidades prisionais. As situações de indisciplina são cada vez mais observáveis na prisão.

(...) é preciso considerar que mudou a composição social das massas carcerárias. Estudos recentes indicam que esta população está se tornando mais jovem e dotada de maior escolaridade, o que pode estar influenciando atitudes de inconformismo e protesto coletivo. (ADORNO, IN, RAMALHO, 2002, p. 12).

Esse modelo de criminoso mais violento, é rejeitado também pelos pobres da área de onde se originam, que por osmose são também perseguidos pela polícia, pois morar na periferia, na favela é carregar os símbolos da criminalidade, aceitando muitas vezes a prática de justiceiros e grupos de extermínio. O que torna ainda atual a reflexão de Foucault: [...] hoje o delinquente pratica uma criminalidade recusada pela população da qual é recrutado, pois a violência da prática repressiva que supostamente a ação desencadeia recai sobre esta mesma população". (FOUCAULT, 1977, p. 245).

Esse tipo de representação sobre as áreas onde moram as populações mais pobres, e sobre eles, tem levado a interpretações simplistas e justificado o desrespeito aos seus direitos civis e políticos destas populações. "Atribuir 0 crime à pobreza, de forma mecânica e simplista, sem levar em conta as mediações culturais, entre outras, ofende os pobres e não explica porque a maioria da população pobre não comete crimes." (SOARES, 2000, p. 110).

\section{Os direitos humanos dos prisioneiros e o direito penal do inimigo}

Defender os direitos humanos dos prisioneiros é atribuir-lhes o estatuto da igualdade e da cidadania, é transformá-los em semelhantes, o que não significa a defesa do seu crime, mas da sua condição humana. Celso Lafer se apropria do referencial teórico arendtiano para demonstrar o lugar dos direitos humanos na atualidade e a pertinência do pensamento de Hannah Arendt na análise do problema dos direitos humanos.

Com efeito, continuam a persistir no mundo contemporâneo situações, sociais, políticas e econômicas que contribuem para tornar os homens supérfluos e sem lugar no mundo[...] a ubiquidade da pobreza e da miséria, assim como a ameaça do holocausto nuclear, a coincidência entre a explosão demográfica e a descoberta das técnicas de automação que podem tornar segmentos da população descartáveis do ponto de vista da produção são, inter alia, situações que evidenciam a relevância e a atualidade das preocupações de Hannah Arendt. (LAFER, 1998, p. 15-16). 
Mesmo que o tema dos Direitos Humanos possa se transformar em um estorvo para aqueles que o relacionam apenas aos direitos dos prisioneiros, devemos registrar a insistência dos movimentos ligados à sua luta, o que tem forçado a população, mesmo a contragosto, a conviver com a sua presença exigindo a observância dos direitos dos grupos incômodos, entre os quais se enquadram os prisioneiros. Estes grupos saem, cada vez mais, dos espaços denunciadores e interferem mais diretamente nos problemas sociais. Sobre a importância da ação dos militantes em direitos humanos é encorajadora a observação de Oliveira.

Trazendo a questão para o nosso tema: O militante constata que apesar, de sua ação, as violações continuam ocorrendo; mas pode ser que muitas outras tenham deixado de ocorrer exatamente porque a sua ação existe! (..) se hoje essas ações são percebidas como violações de Direitos Humanos, e porque a noção de direitos humanos, hoje existe. Existe porque existem movimentos que a sustentam. Nós sabemos como é o mundo em que vivemos. Há nele muito sofrimento, muita violência, muita injustiça e crueldade. Como também há o combate a tudo isso, em nome justamente dos direitos humanos. E se o combate não existisse? (OLIVEIRA, 2007, p. 21).

Para Santos (2002) ONGs, movimentos sociais novos e tradicionais, diversos movimentos religiosos, insistem em discutir os direitos humanos e a desigualdade social, o meio ambiente, os direitos civis e políticos, seus líderes cada vez mais se enquadram na mira dos grupos conservadores. Observamos que mundialmente são vítimas de perseguição, assassinatos, mas marcam cada vez mais a sua presença em espaços políticos e debates sociais. Os direitos humanos aparecem no cenário global numa perspectiva contra hegemônica da luta contra o neoliberalismo. Souza (2002) ainda analisa estas lutas podem se apresentar como fragmentadas, mas não se pode perder de vista os valores de civilidade e alteridade que ensejam.

Estes novos atores sociais na Percepção de Scherer - Warren (2014) estão localizados principalmente nas $\mathrm{ONGs}^{8}$. O mote destas novas relações é a solidariedade e o assistencialismo, ocupando os vazios deixados pelo Estado. Também os Fóruns de debates internacionais, as redes de debate pela internet, as lutas contra - hegemônicas, buscam humanizar o processo de globalização, ampliando os seus espaços democráticos. Em entrevista a Katia Arguello, Luciano Oliveira sobre a atualidade dos direitos Humanos no Brasil e de sua relação com a Democracia, atenta para uma questão importante.

O meu ponto de partida é o lugar de onde falo: A realidade brasileira atual. Nela, o tema dos Direitos Humanos, popular e mobilizador até meados dos anos 80 , vem sofrendo desde então uma crescente degradação a ponto de, hoje em dia, ser francamente desdenhado pela opinião pública, de um modo geral favorável ao combate à criminalidade por métodos

8 - Organizações Não-Governamentais. 
igualmente criminosos: Espancamentos, prisões arbitrárias, justiçando, enfim, todo rol de horrores que historicamente configuram a repressão policial no Brasil. (OLIVEIRA. in ARGUELLO, 1999, p. 172).

Também demonstra que todo esse retrocesso não é apenas uma realidade brasileira, herança de nossa estrutura escravocrata, chama a atenção para o caso francês, mostrando que o antigo Ministro da Justiça, alguém insuspeito que propôs a abolição da pena de morte naquele país, se posiciona em favor da lei de ferro nas prisões. Chama a nossa atenção para o fato de que os acontecimentos estão o tempo todo a nos dizer que democracia e direitos humanos são valores necessariamente coincidentes. (OLIVEIRA. IN: ARGUELLO, 1999, p. 173-174)

Em relação à realidade da prisão brasileira e sua relação com a nova razão penal neoliberal, Nilo Batista expôs algumas reflexões sobre esta criminalização neoliberal no Brasil.

\begin{abstract}
São movimentos paralelos: garantir o monopólio da especulação e a criminalização da economia informal, que vai passar, claro pela droga, mas pega também a prostituição, o jogo do bicho, pega flanelinhas, o horror que a assepsia neoliberal do grande irmão tem com relação as estratégias de sobrevivência dos pobres na periferia[...] O Estado do bem estar tinha um sistema penal que, como todo sistema penal, era uma coisa destrutiva, negativa, porque a pena é o pior modelo de decisão de conflitos. Quando você criminaliza um conflito faz uma opção política. (BATISTA, 2003, p. 29).
\end{abstract}

Apesar de não acreditar na capacidade ressocializadora da prisão, enxerga que o elemento de intervenção do Estado neoliberal é a pena. Sobre a prisão e a socialização continua: "Mas, embora seja ilusório, isso tem uma virtude, você não pode se comprazer com o sepultamento do cara em vida, com uma pena de neutralização, você tem que buscar uma finalidade" (BATISTA, 2009, p. 31). Em relação aos pobres: crimes hediondos, sem progressão de regime, a ideia é o encarceramento, porém para o consumidor: juizados especiais, justiça terapêutica para os viciados da classe média. Verificamos que a difusão do sentimento de impotência, principalmente entre os grupos mais críticos, em relação ao que se fazer com as prisões, qual o seu futuro as posturas acabam por engessar ações sociais que possam tornar a prisão um espaço menos desumanizante.

Segundo Waquant, (2001) o Estado define as áreas pobres das cidades como regiões - problema, como se fossem áreas proibidas, com circuitos selvagens, considerados como territórios de abandono que devem ser evitados e temidos, representados como locais de vícios, de excesso de crimes e marcados pela desintegração social.

O problema teórico - político de Waquant reside no esforço em capturar o processo civilizador, um processo de reestruturação a longo prazo que conta com o Estado monopolizador da violência legítima equipado com redes de 
organizações e pacificações do intercâmbio social. Inscreve-se num percurso de afirmação da cidadania entendida como condição que reconhece "o processo conflituoso e desigual, que precisa ser continuamente conquistado e reassegurado. (PASSETI, 2002, p. 11).

Os debates sobre a Reforma do Estado, baseadas na receita do Consenso de Washington, também se dirigem ao Sistema Penitenciário. Para Minhoto (2000) as políticas de desregulamentação, desconstitucionalização e equilíbrio fiscal se transformam nos grandes imperativos dos mercados globalizados e as funções sociais do Estado são substituídas pelas políticas de mercado, baseadas em critérios de rentabilidade e acumulação.

O argumento para a privatização do Sistema Penitenciário é o da economicidade o barateamento da administração da prisão para o Estado. Ressalta a necessidade de observar que o Estado prende, julga, condena pune e encarcera, em nome da segurança pública, assume obrigações legais e éticas para com os reclusos. No entanto, com a privatização do Sistema Penitenciário, quais serão as leis que regulamentarão as relações de trabalho? A legislação protege os reclusos do trabalho compulsório? Firmas de segurança, candidatas a gerência das unidades prisionais, estão capacitadas para lidar como os direitos dos detentos? Quais as experiências administrativas as credenciam a administrar um Sistema Penitenciário complexo como 0 nosso? Como explicar que as suas propostas não envolvem as unidades de segurança máxima? Ainda é cedo para avaliar, mas muitas destas questões inviabilizam sua privatização (MINHOTO, 2000, p. 27). Reverter o consenso autoritário em torno da sua função e finalidade da pena de prisão é o grande desafio: Waquant defende a necessidade da retomada do Welfere State.

Outra importante reflexão sobre o sistema penitenciário e a nova criminalidade é realizada por Nils Christie. Tomando como exemplo drogados e presidiários que dentro da penalogia neoliberal, são considerados abaixo da serventia. "Sua principal atividade é serem exemplo de condições indesejáveis e também matéria - prima para a indústria de controle". (CHRISTIE, 1998, p. 65). Discute que a função da nova penalogia é a de gerir os grupos rebeldes, preocupação não seria nem a punição nem a reabilitação dos infratores. Ele irá chamar as áreas submetidas a esta lógica de campos de extermínio, podendo estar localizado em qualquer área da cidade ou do campo ou mesmo no sistema prisional. O objetivo seria então penalizar as pequenas infrações como prevenção contra os grandes crimes. (PASSETI, 2002, p. 19). Tanto para Waquant, como para Christie o Estado tornou-se um redirecionador da intervenção, criminalizando a pobreza e constituindo uma indústria de controle do crime. Retoma-se a ideia de um processo civilizador com objetivo de corrigir as incivilidades, mas ressalta os perigos que esta visão engendra, onde "educar e punir se redesenham e perpetuam seu casamento indissolúvel. (PASSETI, 2002, p. 19). E essa lógica perversa se transforma aos poucos em pensamento único, massificado de um projeto civilizador autoritário, determinista que rejeita a pluralidade e tem como base a intolerância.

No desenho da atual política criminal percebemos que o cenário deste debate político marcado pelos defensores da repressão penal, cujas justificativas encontram ressonância na sociedade como paradigma em 
ascensão. Alegam a necessidade de combater a criminalidade, estabelecendo uma reação oficial mais penalizadora com estratégias claras de domínio sobre as áreas produtoras desta criminalidade e grupos mais vulneráveis ao crime. Do outro lado, denunciando os efeitos perversos da penalidade neoliberal se encontram os grupos que propõem a substituição desta política criminal, considerando que a guerra não se faça contra os criminosos, mas contra a pobreza e a exclusão. Ambas pecam pelas consequências que produzem. Enquanto a visão neoliberal centra sua análise no terrorismo penal, a outra enxerga que as políticas de retorno ao Estado Social poderão contribuir para o debate mais realista. Esquecem que como nos lembram Peralva (2000) e Oliveira (1996) é preciso observar mais atentamente para essa nova criminalidade mais letal, menos romântica que não pode ser estudada distante de uma análise mais complexa da realidade brasileira, do processo de redemocratização do país onde se deu seu desenvolvimento, entendendo que o debate não se limite apenas à criminalidade e sua expressão biológica, territorial ou de classes. Mas, dos círculos de violência que as atingem e que fazem da sua indisciplina um mecanismo de sobrevivência e visibilidade social.

\section{Considerações finais}

Os estudos brasileiros sobre o sistema penitenciário se equivocam por transpor sem muitos cuidados as análises de Michel Foucault para a realidade da prisão no Brasil, sem atentar que nossa realidade segue o padrão ibérico, não permitindo, por exemplo, a aplicação da ideia de panóptico, pois a arquitetura prisional não segue o padrão por Foucault analisado. Os estudos clássicos sobre a formação da sociedade brasileira: Gilberto Freire, Roberto da Mata, Sérgio Buarque de Holanda, Raimundo Faoro, Victor Nunes Leal, apontam para as especificidades de termos constituído uma sociedade singular nos trópicos, com características que não são comuns a outros povos, não adequados na moral ou na cultura a sociedade europeia. Assim, os estudos dos problemas brasileiros, exigem a compreensão do funcionamento dos nossos sistemas de valores que em nada se assemelham as sociedades europeias, em particular a francesa, estudada por Foucault. A concepção de panóptico poderá se aplicar as estruturas de $\operatorname{RDD}^{9}$ ou aquelas que a vigilância que tudo ver seja realizada por monitoramento eletrônico que são as propostas de privatização de presídios na atualidade. Michel Foucault é um pensador necessário à compreensão da passagem da pena de suplício para a pena privativa de liberdade, sua obra é riquíssima e nos fornece elementos para compreender os limites da prisão no cumprimento de suas exigências democráticas.

Os desafios dos estudos sobre o sistema penitenciário brasileiro exigem um esforço amplo de buscar interpretar a prisão e os sujeitos privados de liberdade, a partir da teia das inúmeras relações de poder que os envolvem que são micro relações reproduzidas da realidade macro da sociedade brasileira e que tem novas configurações nos espaços de privação de liberdade e se ligam a cultura política existente em nosso país, razão pela qual os fenômenos de coronelismo, clientelismo e populismo necessitam ser revisitados. Os autores da história, da sociologia, da ciência política, do direito e da educação do Brasil

\footnotetext{
9 - Regime disciplinar diferenciado. 
e da América Latina, necessitam compor o arcabouço teórico de nossos estudos sobre a prisão, sem que desprezemos referenciais essenciais tradicionais, mas é necessário que se compreenda que o nosso contexto histórico produziu relações de poder em que o "jeitinho", a privatização dos espaços públicos pelas oligarquias que se mantém no poder até os dias de hoje reproduz uma cultura política de exclusão e violência na sociedade, que por sua vez também se configura na prisão, criando comandos e poderes paralelos ao Estado, extremamente difíceis de serem combatidos pelas linguagens criadas no cotidiano carcerário. Compreendendo a prisão como um espaço distante ainda da experiência do Estado de direito, ela se apresenta como lugar de domínio do medo, da violência e da lei do mais forte, gerando profunda rejeição social da opinião pública.

Sem perder de vista que este ambiente de produção de violência não pode ser invisível no processo democrático, que, na condição de privação de liberdade. Estão confinados sujeitos de direitos, cujos direitos humanos são constantemente violados e que daquele espaço também violam direitos dos outros. Na atual ordem mundial são tratados como descartáveis, as políticas públicas de aprisionamento e endurecimento das penas revelam a descrença em ordem global das políticas de ressocialização. Sendo assim, o debate da afirmação de direitos de criminosos passa a gerar um profundo mal - estar social, na medida em que influenciados pelos programas policiais e pelo crescimento de uma extrema direita que defende medidas exclusivamente repressoras para o enfrentamento do crime e da violência pesquisar sobre os direitos humanos das pessoas privadas de liberdade é atuar numa temática polêmica que atrai a antipatia social e o desejo que os criminosos e os seus famigerados "defensores" não ocupem a paisagem. Tem sido o desejo de uma opinião pública cada vez mais desencantada e pouco esperançosa na capacidade da sociedade e do Estado encontrarem soluções para esse complexo problema social. Mais que dá respostas, neste artigo, nosso desejo é aprofundar a reflexão, é possível acreditar em uma democracia que mantém seres humanos como mantemos em nossas prisões? Quais os caminhos democráticos para o enfrentamento do problema? Como conciliar os valores democráticos numa sociedade que em nome da segurança pública participamos de um consenso social que difunde concepções neonazistas da solução do problema? Se "bandido bom é bandido morto" para onde caminhamos? Está na hora de repensar!

\section{Referências}

ADORNO, S. IN, RAMALHO, J. R. O Mundo do Crime: A Ordem pelo avesso. SP: IBCCRIM, 2002.

AMNESTY INTERNATION PUBLICATIONS. Eles nos Tratam Como Animais.

Tortura e Maus - Tratos no Brasil. Publicado no Brasil, outubro de 2001.

BATISTA, N. Todo Crime é Político. Revista Caros Amigos, Ano VII, N. 77, agosto de 2003.

BRASIL. Lei de Execução Penal - Lei no 7.210, de julho de 1984.

CARVALHO, Í.M. O Nordeste e o Regime Autoritário. São Paulo: HUCITECSUDENE, 1987.

CELIS, J, B E HULSMAN, L. As Penas Perdidas. Paris: Luam,1996. 
CHAVES, J. O Problema do Direito em Michel Foucault. Porto Alegre: Juruá, 2010.

CHRISTIE, N. A Indústria do Crime. SP: forense, 1998.

DAMATTA, Roberto. A Casa e A Rua: Espaço, Cidadania, Mulher E Morte no Brasil. Rio de Janeiro: Rocco, 1997.

FAORO, R. Os Donos do Poder. SP: Editora Globo, 2001.

FOUCAULT, Michel. Microfísica do Poder. Rio de Janeiro: Civilização, Brasileira, 1979. 1984.

A Verdade e as Formas jurídicas. In Cadernos da PUC/RJ: Rio de Janeiro,

Vigiar e Punir: A História da Violência nas Prisões. Petrópolis: Vozes, 1994.

História da Sexualidade. A vontade de Saber. Vol. 1. Rio de Janeiro: Graal, 1996.

FREITAG, B. Política Educacional e Indústria Cultural. São Paulo: Cortez, Editores Associados, 1989.

GARCIA, A. Org. Pesquisa Mutirão Escolar: Novos Rumos do Clientelismo na Paraíba, UFPB, Centro de Educação. Departamento de Habilitações Educações Pedagógicas. João Pessoa 1991.

GERMANI, G. Política e Sociedade em Uma Época de Transição. Buenos Aires: Paidos, 1962.

GOFFMAN, E. Trad: Dante Moreira Leite. Manicômios, Conventos e Prisões. São Paulo: Perspectiva, 2005.

HOLANDA. S, B. Raízes do Brasil. São Paulo: Companhia das Letras, 1997.

JAGUARIBE, H. Crisis y Alternativas de América Latina: reforma e revolución.

Buenos Aires: Pardos, 1973.

LAFER, C. A. Reconstrução dos direitos Humanos: Um diálogo com o pensamento de Hannah Arendt. São Paulo: Companhia de Letras, 1998.

LEAL, V.N. Coronelismo, Enxada e Voto: O Município e o Regime Representativo no Brasil. 2. e. São Paulo: Alfa-ômega, 1975.

LEMOS - NÉLSON, A.T. Criminalidade Policial, Cidadania e Estado do Direito. Caderno CEAS, Jan/fev, 2002.

MAIA, L.M. Tortura no Brasil. A Banalidade do Mal, In. Direitos Humanos: Desafios do século XXI: Uma Abordagem Interdisciplinar. (org) Rubens Pinto Lyra. Brasília: Jurídica: 2002.

MARTY, M. D. Modelos e Movimentos de Política Criminal. Tradução Edmundo Oliveira. Rio de Janeiro: Revan, 1992.

MINHOTO, L. D. Privatização de Presídios e Criminalidade: A Gestão da violência no Capitalismo Global. SP: Max Limonad, 2000. $\overline{1996 .}$

. in: ARGUELLO. Direito e Democracia. Editora Letras Contemporâneas: SP:

OLIVEIRA, L. Neo-miséria e Neo-nazismo: Uma Revisita à Crítica à Razão Dualista. Política Hoje, Revista do Mestrado em Ciência Política da UFPE, Recife: Universitária, V.II, M.4, Jul a Dez de 1995, Ano II, V. III, N.5, Jan a Jun. de 1996. 
._. L Luta Pelos Direitos Humanos. Uma Nota a Favor do Otimismo. Revista do GAJOP: Segurança, Justiça e Cidadania. Recife: GAJOP, 1996.

OLIVEIRA, L. Política Criminal e Alternativas à Prisão. Rio de Janeiro: Forense, 2001.

PASSETI, E. Cartografia de Violências. Revista Serviço Social e Sociedade, N. 70: violência. Ano XXIII, julho. SP: Cortez, 2002.

PERALVA, A. Violência e Democracia: O Paradoxo Brasileiro. São Paulo: Paz e Terra, 2000.

PINHEIRO, P. S. MENDEZ, Juan E. O'DONNELL, Guilhermo. Democracia, Violência e Injustiça: O não-Estado de Direito na América Latina, São Paulo: Paz e Terra, 2000.

PIOVESAN, F. Direitos Humanos e Direito Constitucional Internacional. 3.Ed, São Paulo: Mas Limonad, 2005.

ROMANELLI, O. de O. História da Educação no Brasil. Petropólis: Vozes, 1978

RUDINICK, D. Prisão, Direito Penal e Respeito aos Direitos Humanos. SP: Hucitec, 1999.

QUEIROZ, M. I.P de. O Mandonismo Local na Vida Política Brasileira. São Paulo Alfa - Ômega, 1976.

SALLA, F. Rebeliões nas Prisões brasileras. Revista Serviço Social e Sociedade, N. 67 Ano XXII, julho. SP: Cortez, 2000.

SANTOS, B. S. Crítica da Razão Indolente. Contra o desperdício da Experiência. SP: Cortez, 2002.

SHERER - WARREN, I. Cidadania Sem Fronteiras: Ações Coletivas na Era da Globalização. SP: Hucitec, 2013.

SMITH.A. Researching Causes of Groos Rights Violations: A Programe. Leiden: Center for the study of social conflict. s/d.

SOARES, L.E. Meu Casaco de General: Quinhentos Dias no Front da Segurança Pública do Rio de Janeiro. São Paulo: Companhia das Letras, 2000.

SOUZA, H. In. CNBB. SEMINÁRIO: Exigências Éticas da Ordem Democrática. SP: Loyola, 1989.

TELLA, T. de. Clases Sociales y Estructuras Políticas. Buenos Aires: Pardos, 1974.

THOMPSON, A. A Questão Penitenciária. Rio de Janeiro: Forense, 2000.

VARELA, D. Estação Carandirú. SP: Companhia das Letras, 2002.

Em Busca das Penas Perdidas. RJ: Loyola, 2007.

WAQUANT, Loic. As Prisões da Miséria. Tradução: André Telles. Rio de Janeiro: Jorge Zahar Editor, 2001

WEFFORT, Francisco. Classes Populares e Desenvolvimento: Contribuição ao Estudo do Populismo. Santiago do Chile: Instituto Latino-americano de Planificação Econômica y Social, CEPAL, MIMEO, 1968.

ZAFFARONI, E, R. Criminologia e Ciência Criminal. SP: Editora GZ, 2010. 